\title{
RURAL TOURISM FOR THE SAVE OF AGROBIODIVERSITY AND THE SOLUTION OF SOCIO-ECONOMIC PROBLEMS OF RURAL
}

\section{Lokutova Olena*, Onopriichuk Diana}

\author{
National University of Life and Environmental Sciences of Ukraine, Kyiv, Ukraine
}

Received 25. 6. 2017

Revised 29.6. 2017

Published 29.11.2017

The aim of the article is to examine the theoretical foundations and practical approaches to the development of rural tourism, and also to analyze the relevance and necessity of further development of rural tourism in the context of sustainable development. First of all, we consider the terminology, concepts, necessary conditions which contribute to the development of rural tourism and sustainable tourism, its environmental aspects and the main differences from traditional tourism. The second important component of rural tourism is its significant impact on the solution of socio-economic problems of the village (self-employment and the problem of unemployment, additional income of the rural residents as well as the preservation of architectural and cultural heritage and folk traditions). Thus, considering the importance of rural tourism as a special kind of activity of rural residents (family hospitality), there is a need to further improve its legislative base, in particular, the adoption of the law of Ukraine "About rural green tourism", the project of which was developed in 2012. Another important step for the effective development of rural tourism is to popularize it, especially in the regions of Central, Eastern and Southern Ukraine. Consulting activities (consultative support), holding conferences, seminars, training schools and other events at the level of regional and district administrations will raise the interest of the village population, and thus contribute to solving the social, economic and environmental problems of the regions. A special role in this process is played by agrarian universities (in particular, the National University of Life and Environmental science of Ukraine), institutes for improving the skills of agricultural personnel.

Keywords: rural green tourism; ecology; agrobiodiversity; sustainable tourism; agrorecreational clusters

\section{Introduction}

Further development of civilization is impossible without a comprehensive campaign, which is reflected in the concept of sustainable development - an economic growth model in which the use of resources is aimed at meeting human needs while preserving the environment for the benefit of future generations. The consumer, irresponsible attitude to nature and resources generates new global problems, the main among them is environmental safety and conservation of agrobiodiversity. Tourism is one of the dynamically developing sectors of the world economy. But the rapid pace of development of tourism and its mass led to negative changes in the natural environment in certain regions. Polluted beaches, areas with excessive noise, developed erosion, impoverished landscape became unfit for recreation. Thus, tourism began to destroy the foundations of its existence. Among all types of tourism only rural tourism does not have a negative impact on the environment, but on turnover, contributes to its preservation.

\footnotetext{
*Corresponding author: Olena Lokutova, National University of Life and Environmental Sciences
} of Ukraine, Kyiv, Ukraine, $\bowtie$ e.veridar@ukr.net 
In most countries of the world, rural tourism is considered as an integral part of the complex socioeconomic development of the village, as one of the means to solve many rural problems, including environmental ones. At the present stage of the development of agriculture and rural areas, the development of rural green tourism on a scientific basis becomes especially important.

It should be noted that over the past 10 years, the development of rural green tourism in Ukraine has achieved significant success, its mass popularity and popularity is rapidly growing. The significant impetus to the development of rural tourism made the last financial crisis, since recreation in rural areas is not as expensive as at foreign resorts. Another important stimulating factor is the popularization and information and consulting support for the development of this type of recreation (КальнаДубінюк, 2016).

The aim of our work was to study theoretical approaches and practical bases for the development of rural green tourism in the context of ecology, save of agro-biodiversity and the solution of socioeconomic problems of the rural.

\section{Materials and methodology}

The methodological basis of the research is the method of analysis and synthesis, which provides the systematic approach to the study of processes and phenomena, which makes it possible to examine the issue from the standpoint of the integrity and continuity of the object and its environment, goals and methods, tools and monitoring tools.

The system approach allows identifying problematic aspects of the development of rural tourism, which should be implemented by improving the legislative base (adopting the law of Ukraine "About rural green tourism") and improving the state policy of supporting the agro-industrial complex and development of rural areas (creation agrorecreational clusters), development of a nature reserve fund with the involvement of the territorial communities of the village and business entities, as well as the formation of local educational and practical centres for rural communities. This will improve the socio-economic and environmental situation in general, which in the final stage will allow to achieve positive changes in the quality of life of the rural population.

Opportunities for the development of rural green tourism have been studied for a long time. Their decision was devoted to their work: M. Rutinsky, Yu. Zinko, V. Vasiliev, M. Kropivko, T. Kalna-Dubinyuk, A. Beydyk and etc. However, the relevance of the questions presented and their insufficient scientific and methodological support need further research.

\section{Results and discussion}

Rural tourism is a specific form of recreation in private farms in rural areas with the use of the property and labour resources of a personal peasant, subsidiary or farming enterprise, natural and recreational characteristics of the locality as well as cultural, historical and ethnographic heritage of the regions.

Rural tourism develops on the basis of personal peasant farming (The law of Ukraine "About personal farming"). This model is successfully implemented in European countries, where the main component is state support for the development of a network of guest rooms based on the available housing stock in rural areas. The main figure in the organization of recreation in the village is the rural family, which provides housing, provides food and introduces the characteristics of the countryside.

Rural tourism can effectively develop and function in such territories as:

- national parks and specific protected areas; 
- villages, recreation areas and holiday zones;

- forest fund and natural phenomena;

- monasteries and sacred places;

- small cities with characteristic architecture, life, culture;

- monuments of popular culture in the open air.

The terminology of rural green tourism includes a number of generally accepted environmental concepts. Sustainable tourism is a modern concept of tourism development based on the principles of sustainable development, which makes it possible to meet all the existing needs, but at the same time to provide similar opportunities for future generations. The concept of sustainable development has united three main components: economic, social and environmental. It is known that the concepts of ecology and agrobiodiversity are closely related. Agrobiodiversity, covering the diversity of living organisms (plants, animals and microorganisms), which are grown in agricultural regions, contribute to agricultural production.

The concept of "rural green tourism" (green tourism), natural tourism (nature tourism) is close in meaning to the term "ecological tourism". The US Ecotourism Union provides such a definition of ecotourism common in Western science: "Ecotourism is a journey to places with relatively untouched nature that do not lead to a disruption of ecosystem integrity, in order to gain an understanding of the natural and cultural-ethnographic features of the locality, which creates Such economic conditions, when the protection of nature becomes beneficial to the local population" (Рутинський та Зінько, 2008).

The main driving force behind the rapid development of rural green tourism, ecotourism is the rapidly growing demand for recreation in nature, which is determined by the increasing in the discrepancy of the modern human environment with its physiological and psychological needs.

From traditional tourism ecotourism is characterized by the following features:

- the advantage of natural, rather than cultural tourism objects;

- sustainable use of nature;

- less resource and energy intensity;

- direct participation in the social and economic development of the territories;

- ecological education of tourists (Горішевський та ін., 2005).

Ecotourism includes all types of tourism that have minimal or no effect on the environment and provide a balance between the tourist, natural and economic activities. Such ecologically safe kinds in tourism consider walking tours bicycle and ski travel, mountaineering, supervision over the nature, navigation on kayaks and a canoe, sports sea fishing, walks in mountains and etc.

"Union for the promotion of rural green tourism of Ukraine" (Union), which was founded in 1996, has significant role in the process of becoming a rural tourism in Ukraine. The purpose of its activity is: popularization of rest in the Ukrainian village; assistance to development of rural infrastructure and self-employment of the rural population; save of cultural heritage and environment (Web pages Union).

Over the years of its activity the Union has done a lot for the development of rural green tourism in Ukraine:

- the term "rural green tourism" was introduced in the legal field of Ukraine (1996).

- passed Law of Ukraine "On Private Farm Economy", a number of legislative acts, decrees of the President of Ukraine, orders and resolutions of the government; 
- since 1997 for the popularization of rest, the village magazine "Green rural tourism" has been published;

- since 2003 all-Ukrainian exhibition-fair of rural tourism annually "Ukrainian village invites" is held and etc.

In 2004 and 2008, the Union introduced programs of voluntary environmental marking "Green house" (Figure 1) and the categorization of services "Ukrainian guest house" (Figure 2), as well as a school of inspectors for the voluntary categorization was opened.

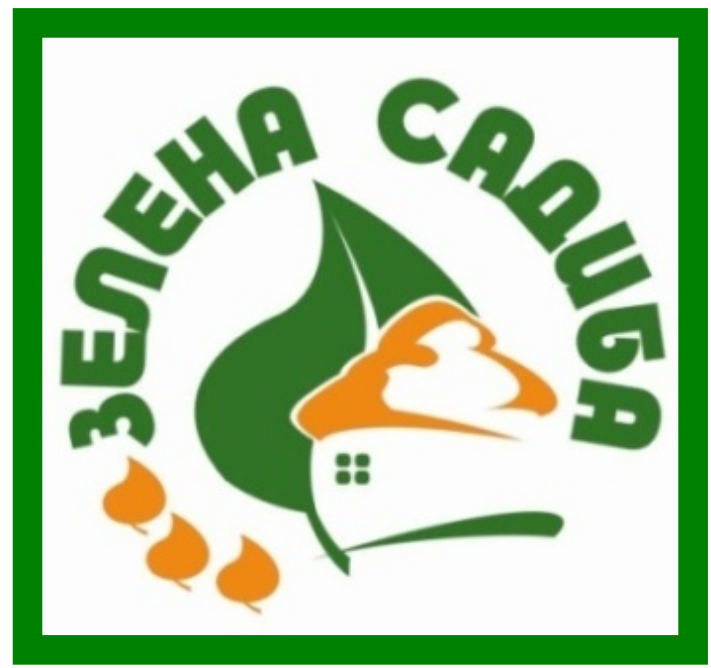

Figure 1
Sign of environmental Marking "Green house"

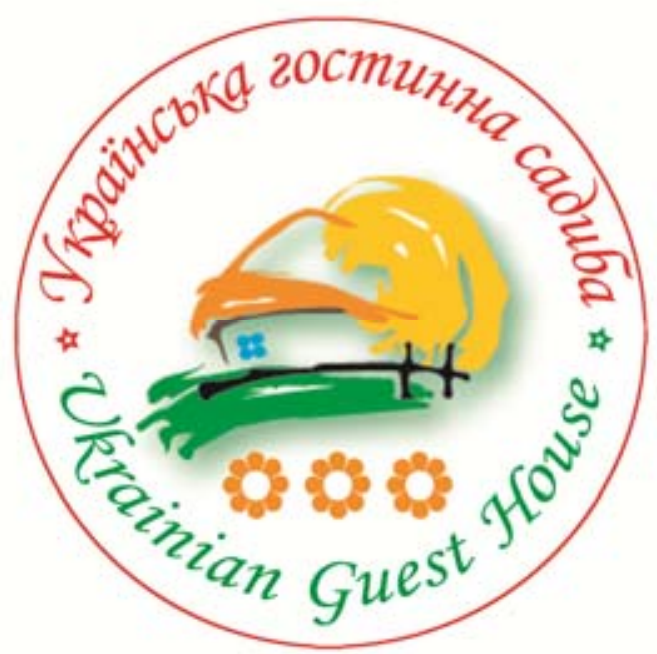

Figure 2 Sign of environmental Marking "Ukrainian guest house"

The program of ecological marking "Green house" was developed on the basis of a number of European analogues, in particular Latvian and Polish experience. The program contributes to the growth of the environmental consciousness of the owners of farmsteads and tourists, it is used as a marketing tool to achieve market success and improve the economic efficiency of agro-tourism services, contributes to the improvement of the environment.

The "Green Manor" is a testament to the fact that the estate meets a number of requirements for preserving the environment and supporting the sustainable development of the region.

Sustainable tourism is based on the following principles:

- environmental protection, minimization of damage in the process of tourism, environmental supervision of the state of tourism development of the territories;

- controlled use of technologies of tourist service, first of all motor transport, energy, potable water, etc.;

- social justice with respect to local communities, that is, profits and other benefits from tourism should be distributed on an equal footing, taking into account the local population, and not move to foreign investors and the national elite, etc.

\section{Conclusions}

The positive impact of rural green tourism on the solution of the social and economic problems of the village is that it expands the employment of the rural population, especially women, and gives 
the peasants additional income, expands the employment opportunities of the farmer not only in the production sector, but also in the service sector. Rural tourism is not only a plus for the economy, environmental protection, improving the environmental situation, as well as creating new jobs, stimulating the flow of young professionals in rural areas.

Ukraine being an agrarian country has great potential for successful development of rural tourism, therefore the most important issue is the adoption of the Law of Ukraine "About rural green tourism". This will enable:

- to improve the legal regulation of relations in the sphere of rural green tourism, which will comprehensively encourage citizens of Ukraine to participate in its development;

- in the State Budget of Ukraine and local budget projects, annually provide funds for the development and implementation of programs for the development of rural green tourism, as well as for the promotion and advertising of rural green tourism in Ukraine and abroad;

- to recognize rural tourism as an important subsidiary of the Ukrainian tourism industry and an important factor in ensuring self-employment and improving the living standards of the rural population, etc.

Another important factor in the successful development of rural tourism is informational and consultative support for the population: holding seminars, training schools, conferences and other events that popularize rural tourism. This is especially important for the regions, where its development is hampered (Centre, East and South of Ukraine). A special role in this process had agrarian universities (in particular, the National University of Life and Environmental science of Ukraine,), institutes for improving the skills of agricultural personnel, which have the material, technical and pedagogical base for organization such events.

\section{References}

Union for the Promotion of Rural Green Tourism in Ukraine. Спілка сприяння розвитку сільського зеленого туризму України. Available at: http://www.greentour.com.ua.

The law of Ukraine "About personal farming" from 15. 5. 2003, no. 742-IV. Available at: http://zakon0.rada. gov.ua/laws/show/742-15

Горішевський, П., Васильєв, В., Зінько, Ю., Коберніченко, Т. 2005. Сільський зелений туризм:організація діяльності. Посібник. Київ: НМЦ «Освіта». 128 с.

Кальна-Дубінюк, Т. 2016. Основи управління та організації відпочинку в агрооселях. Інформаційні матеріали до семінару з дорадництва для власників агроосель. Кальна-Дубінюк Т.П., Локутова О.А.,. Кудінова І.П, Рибак Л.Х., Мосіюк С.І., Самсонова, В.В., Бесчастна М.В. Серія 3. Сільський зелений туризм. 3-тє видання за редакцією В.П. Васильєва. Ніжин: Видавець ПП Лисенко М. 103 с.

Рутинський, М., Зінько, Ю. 2008. Сільський туризм. Навчальний посібник. К.: Знання. 271 с. 